Андрущак C. M., andrushchakyevheniya@gmail.com, ORCID ID: 0000-0001-5976-2892,

к.е.н., доч., дочент кафедри фінансів, громового обігу та кредиту, Львівський національний університет імені Івана Франка, м. Львів

Фуфалько В. С.,

fufalkovlada@gmail.com, Researcher ID: AAY-6111-2021,

магістр, Львівський національний університет імені Івана Франка, м. Львів

\title{
ВПЛИВ ФІНАНСОВО-ЕКОНОМІЧНИХ ЧИННИКІВ НА УПРАВЛІННЯ КРЕДИТНИМ ПОРТФЕЛЕМ КОМЕРЦЙНОГО БАНКУ НА ПРИКЛАДІ АТ АКБ “ЛЬВІВ”
}

\begin{abstract}
Анотація. В статті розглянуто основні чинники, які впливають на формування кредитного портфеля банку, а також ризики, які з ними пов'язані. Очінка фінансово-економічних передумов управління кредитним ризиком у банківській системі України проводиться з метою створення ефективної системи управління ним. У процесі дослідження було розглянуто основні типи кредитного портфеля банків. Визначено, щчо тип кредитного портфеля формується залежно від мети діяльності банку. Зазначено, щзо кредитний портфель банку варто розглядати як сукупність активів, щзо піддається оціниі, сегментащії, класифікаџії та управлінню. Така необхідність зумовлена потребою в оцінці дохідності, ризиковості, ліквідності не лише кожної операції, але й їх сукупності. Охарактеризовано зовнішні та внутрішні чинники, які впливають на кредитний портфель банку. Виявлено негативний вплив спалаху пандемії, викликаний вірусом COVID-19, на економічну активність учасників кредитного ринку. Визначено, що головним завданням системи управління кредитним ризиком банку $\epsilon$ мінімізачія кредитного ризику при забезпеченні достатнього рівня прибутків з метою збереження коштів вкладників і підтримання фінансової стабільності банку. Досліджено загальні методи управління кредитними ризиками. Виокремлено заходи, які вживав Банк “Львів” для нівелювання кредитних ризиків, спричинених вірусом COVID-19. 3 метою визначення рівня ефективності кредитної політики банку проаналізовано сучасний стан кредитного портфеля АТ АКБ “Львів”. Також досліджено динаміку кредитного портфеля Банку “Львів” за період 2017-2020 роки. Під час дослідження виявлено вплив фінансово-економічних чинників на зміни у структурі кредитного портфеля Банку “Львів”. Визначено напрями вдосконалення управління кредитним портфелем комериійного банку в умовах економічної нестабільності.
\end{abstract}

Ключові слова: кредитний портфель, кредитний ризик, кредитна діяльність, фактори впливу, управління, аналіз.

Andrushchak Y. M.,

andrushchakyevheniya@gmail.com, ORCID ID: 0000-0001-5976-2892,

Ph.D., Associate Professor, Associate Professor of the Department of Finance, Money Circulation and Credit, Ivan Franko National University of Lviv, Lviv

Fufalko V. S.,

fufalkovlada@gmail.com, Researcher ID: AAY-6111-2021

Master's degree student, Ivan Franko National University of Lviv, Lviv

\section{THE INFLUENCE OF FINANCIAL AND ECONOMIC FACTORS ON THE CREDIT PORTFOLIO MANAGEMENT OF A COMMERCIAL BANK ON THE EXAMPLE OF JSCB "LVIV"}

\footnotetext{
Abstract. The article discusses the main factors that affect the formation of the bank's loan portfolio, as well as the risks associated with them. Assessment of financial and economic preconditions of credit risk management in the banking system of Ukraine is carried out in order to create an effective management system. In the course of the research the main types of banks' loan portfolio were considered. It is determined that the type of loan portfolio is formed depending on the purpose of the bank activities. It is noted that the bank's loan portfolio should be considered as a set of assets that can be assessed, segmented, classified and managed. This need to assess the profitability, risk, liquidity not only of each operation, but also their totality. External and internal factors that affect the bank's loan portfolio are described. The negative impact of the pandemic outbreak caused by the COVID-19 virus on the economic activity of
} 
credit market participants has been revealed. It is determined that the main task of the bank's credit risk management system is to minimize credit risk while ensuring a sufficient level of profits in order to save depositors' funds and maintain the bank's financial stability. General methods of credit risk management are studied. The measures taken by Bank "Lviv" to mitigate credit risks caused by the COVID-19 virus are highlighted. In order to determine the level of efficiency of the bank's credit policy, the current state of the loan portfolio of JSC JSCB "Lviv" was analyzed. The dynamics of the loan portfolio of Bank "Lviv" for the period 2017-2020 was also studied. The study revealed the impact of financial and economic factors on changes in the structure of the loan portfolio of Bank "Lviv". The directions of improvement of management of a credit portfolio of a commercial bank in the conditions of economic instability are defined.

Key words: loan portfolio, credit risk, credit activity, factors of influence, management, analysis.

\section{JEL Classification: G21 \\ DOI: https://doi.org/10.36477/2522-1205-2021-64-04}

Постановка проблеми. Для комерційних банків надзвичайно важливо ефективно здійснювати контроль та управління кредитною діяльністю банку, а саме: оцінкою кредитного портфеля, адже кредитна діяльність приносить основні прибутки банківській установі. Зважаючи на економікополітичну ситуацію в країні та світі, на сьогодні постає питання ефективного управління кредитною діяльністю банку. Важливо вчасно виявити й оцінити ризики, які впливають на його діяльність. Неефективне управління кредитним портфелем та зростання проблемних кредитів призводить до підвищення ризиків здійснення кредитних операцій, а це, своєю чергою, веде до настання збитків та втрати вкладених ресурсів, тому основне завдання менеджменту банків - це вдосконалення механізму управління кредитним портфелем.

Аналіз останніх досліджень і публікацій. Дослідженням теоретико-методологічних основ кредитування, аналізу його результатів, а також кредитної політики присвячено багато робіт вітчизняних економістів, серед яких: Білик М. Д., Вовк В. Я., Жукова Н. К., Кузнєцова Л. В., Мороз А. П., Савлук М. І., Юркевич О. М. та інші. Проте, незважаючи на велику кількість досліджень, кредитна діяльність банку повинна постійно аналізуватися в сучасних умовах розвитку країни. Сучасний кредитний аналіз необхідний для управління якістю кредитної діяльності, оскільки кредити є основною частиною активів.
Постановка завдання. Метою статті $\epsilon$ розкриття впливу фінансово-економічних чинників на формування кредитного портфеля банку та аналіз структури кредитного портфеля банківської установи.

Виклад основного матеріалу дослідження. Формування кредитного портфеля є одним із основоположних моментів у діяльності банку, що дозволяє більш чітко виробити тактику і стратегію розвитку комерційного банку, його можливості кредитування клієнтів і розвитку ділової активності на ринку [2]. Залежно від мети банк формує кредитний портфель певного типу. Тип портфеля - це характеристика портфеля, яка базується на співвідношенні прибутку та ризику. Основні типи кредитного портфеля наведені в табл. 1 [3].

На кредитний портфель банку впливає велика кількість чинників, насамперед це: зміна зовнішніх умов функціонування банківської системи України, наслідки пандемії, нестабільна економічна та фінансова ситуація, знецінення національної валюти, військові дії на сході країни, а також недосконалість методів боротьби 3 проблемними кредитами, оцінка параметрів кредитів, недостатнє використання інструментів та механізмів випереджаючого виявлення проблемних кредитів тощо.

Таблицяя 1

Основні типи кредитного портфеля*

\begin{tabular}{|l|l|}
\hline \multicolumn{1}{|c|}{ Тип портфеля } & \multicolumn{1}{|c|}{ Характеристика } \\
\hline Портфель доходу & $\begin{array}{l}\text { Орієнтований на кредити, які надають стабільний дохід, отримання якого харак- } \\
\text { теризується мінімальними ризиками та постійною своєчасною виплатою від- } \\
\text { сотків }\end{array}$ \\
\hline Портфель ризику & Портфель переважно складається з кредитів із високим рівнем ризику \\
\hline Збалансований портфель & $\begin{array}{l}\text { Раціональне поєднання кредитів різного типу як високоризикованих, так і з } \\
\text { низьким рівнем ризику }\end{array}$ \\
\hline
\end{tabular}

*Джерело: [3]. 


\section{Herald of Lviv University of Trade and Economics. Economic Sciences. № 64, 2021}

Зовнішні чинники прийнято розподіляти наступним чином:

1) на рівні держави: політична ситуація, економічні зміни, стан фінансового ринку, технічний прогрес і соціальне середовище;

2) на рівні банківської системи: загальний стан банківської системи, конкуренція, правила регулювання банківської діяльності.

Внутрішні фактори впливу пов'язані з величиною банківського капіталу, кредитною політикою банку, досвідом і кваліфікацією персоналу, рівнем дохідності та ризикованості напрямів розміщення кредитних ресурсів, а також сектором ринку, на який орієнтується банк.

Протягом 2020 року спостерігалося значне потрясіння світового ринку, викликане спалахом вірусу COVID-19. Уряд України вживав різні заходи для стримування спалаху пандемії. Економічними наслідками цього стали підрив підприємницької та господарської діяльності в Україні, що тягне за собою зростання безробіття та зниження доходів бізнесу та домогосподарств, та зростання економічної невизначеності, що відображається на обмінних курсах [2].

Необхідність розглядати всі кредитні операції як єдине ціле зумовлена потребою в оцінці дохідності, ризиковості, ліквідності не лише кожної операції, але й їх сукупності. Це дає можливість аналізувати загальну кількість кредитних операцій із клієнтами банку на певну дату та частку окремої операції в їх загальній кількості.

Головним завданням системи управління кредитним ризиком банку $є$ мінімізація кредитного ризику при одночасному отриманні достатніх прибутків 3 метою збереження коштів вкладників i підтримання фінансової стабільності банку. В той же час кредитний ризик є невід'ємною складовою процесу існування банку на ринку банківських послуг. Саме тому кредитний ризик $є$ для банку особливим об'єктом аналізу та управління, оскільки дохід від банківської діяльності є залежним від ефективності управління кредитним ризиком. Більше того, зростаючий кредитний ризик трансформується у головне джерело банківського ризику загалом. Тому актуального значення набуває оцінка фінансово-економічних передумов управління кредитним ризиком у банківській системі України 3 метою створення ефективної системи управління ним [3].

У Банку “Львів" створена система управління ризиками, яка має забезпечувати безперервний аналіз ризиків 3 метою прийняття своєчасних та адекватних управлінських рішень щодо пом'якшення ризиків та зменшення пов'язаних із ними втрат та грунтується на розподілі обов'язків між підрозділами банку із застосуванням моделі трьох ліній захисту:

1) на рівні бізнес-підрозділів та підрозділів підтримки діяльності банку. Вони несуть відповідальність за поточне управління цими ризиками та здійснюють заходи з контролю;

2) на рівні Вертикалі управління ризиками;

3) на рівні Служби внутрішнього аудиту, яка здійснює незалежну оцінку ефективності діяльності першої та другої ліній захисту та загальну оцінку ефективності системи внутрішнього контролю.

Виклики, пов'язані 3 пандемією, спонукали Службу внутрішнього аудиту в 2020 році оперативно реагувати на наявну ситуацію: переходити на віддалений режим роботи, інтенсивно впроваджувати і використовувати в щоденній діяльності цифрові технології, поглиблювати компетенції персоналу, підлаштовувати режим комунікацій під наявні обмеження та проводити спеціалізовані аудити. Ключовим викликом стало питання практичної організації робочих процесів за допомогою онлайн-рішень і IT-платформ. У цілому Банк “Львів" успішно впровадив дистанційний режим роботи. Основними заходами управління Служби внутрішнього аудиту були:

- виконання принципів побудови безперервності бізнесу;

- питання формалізації і впровадження Плану відновлення діяльності та його тестування;

- вдосконалення елементів системи управління інформаційною безпекою;

- дотримання принципів управління кредитними ризиками, забезпечення якісного фінансовоекономічного аналізу позичальників;

- вдосконалення ефективності організації операційного контролю;

- впровадження додаткових методів контролю у сфері фінансового моніторингу.

За рахунок вищої бізнес-активності порівняно 3 більшістю конкурентів банківського сектору в цілому Банк “Львів" досягнув посилення своїх ринкових позицій. Порівняно 3 кінцем 2019 року банк піднявся на одну позицію за сумою активів і станом на кінець 2020 р. займає 30 місце за цим показником із 72 діючих в Україні банків [2].

Розглянемо сучасний стан кредитного портфеля АТ АКБ “Львів” за 2017-2020 pр. (рис. 1). Для цього визначимо, яку частину активів банку складають кредитні операції банку за відповідний період.

Найбільшу питому вагу в структурі активів АТ АКБ “Львів" займають кредити та заборгованість клієнтів. У 2017 р. вони становили 55,6\%, у 2018 p. $-58,0 \%$, а в 2020 р. $-60,8 \%$, тож ми бачимо чітку тенденцію до зростання частки заборгованості клієнтів впродовж досліджуваного періоду.

На основі річної фінансової звітності проаналізуємо динаміку та структуру кредитного портфеля за суб'єктами кредитування. 3 табл. 2 видно, що протягом 2017-2020 рр. існувала чітка тенденція підвищення обсягів кредитування Банку “Львів", що $\epsilon$ позитивним фактором. Показник темпу зростання за аналізований період склав $205,6 \%$. 


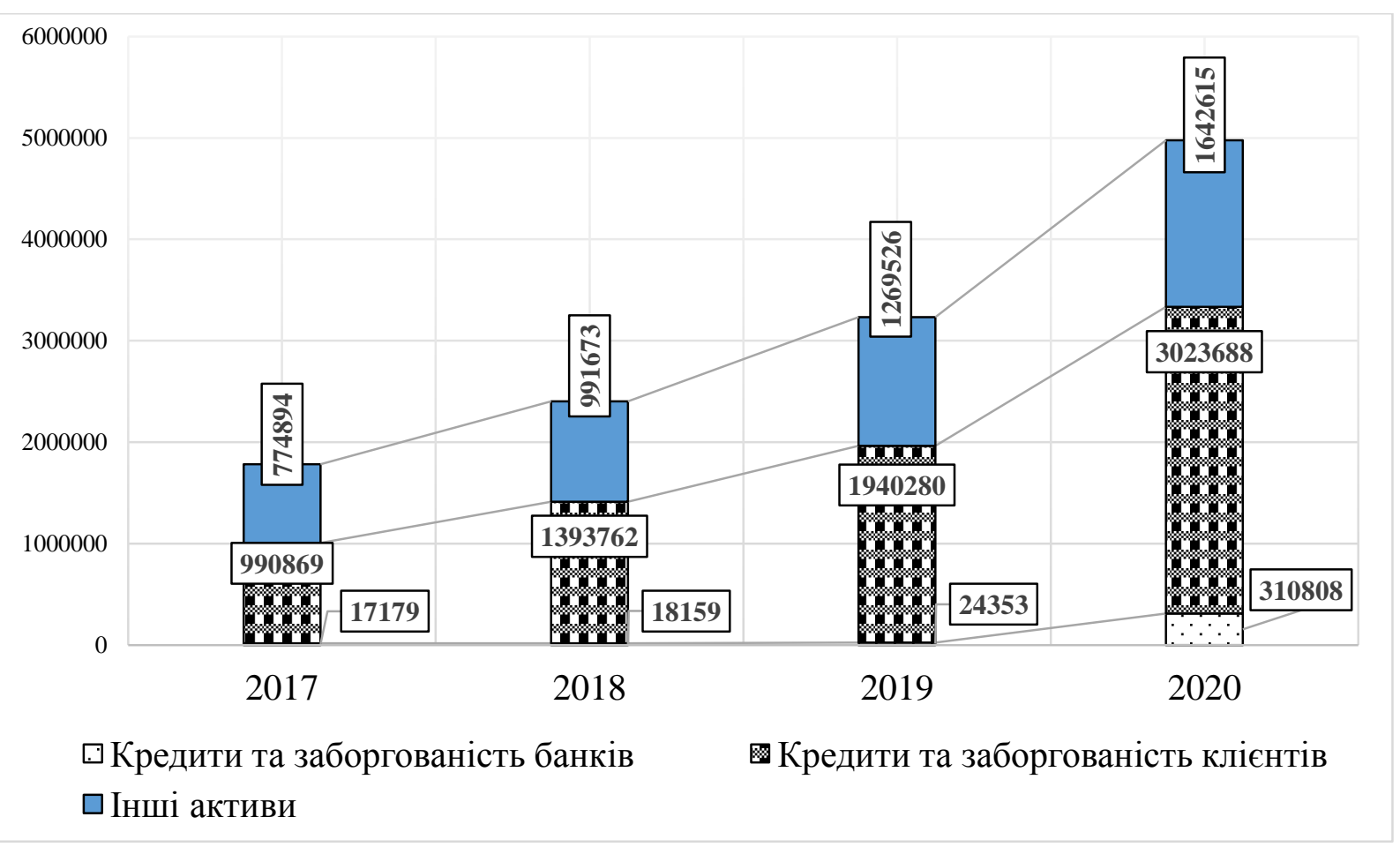

Рис. 1. Структура активів АТ АКБ “Львів” у 2017-2020 рр., тис. грн

Джерело: складено автором на основі [5], [6].

Таблиияя 2

Структура кредитного портфеля АТ АКБ “Львів" y 2017-2020 pp.*

\begin{tabular}{|c|c|c|c|c|c|c|c|c|c|}
\hline Показ- & \multicolumn{2}{|c|}{2017} & \multicolumn{2}{|c|}{2018} & \multicolumn{2}{|c|}{2019} & \multicolumn{2}{|c|}{2020} & \multirow[b]{2}{*}{$\begin{array}{c}\text { Темп } \\
\text { зростання }\end{array}$} \\
\hline $\begin{array}{l}\text { Суб'єкти } \\
\text { кредиту- } \\
\text { вання }\end{array}$ & $\begin{array}{c}\text { Обсяг, } \\
\text { тис. } \\
\text { грн }\end{array}$ & $\begin{array}{c}\text { Пито- } \\
\text { ма } \\
\text { вага, \% }\end{array}$ & $\begin{array}{c}\text { Обсяг, } \\
\text { тис. грн }\end{array}$ & $\begin{array}{c}\text { Пито- } \\
\text { ма } \\
\text { вага, \% }\end{array}$ & $\begin{array}{c}\text { Обсяг, } \\
\text { тис. грн }\end{array}$ & $\begin{array}{c}\text { Пито- } \\
\text { ма } \\
\text { вага, \% }\end{array}$ & $\begin{array}{c}\text { Обсяг, } \\
\text { тис. грн }\end{array}$ & $\begin{array}{l}\text { Пито- } \\
\text { ма } \\
\text { вага, \% }\end{array}$ & \\
\hline $\begin{array}{l}\text { Кредити } \\
\text { фізичним } \\
\text { особам }\end{array}$ & 79081 & 8,0 & 341191 & 24,5 & 642169 & 33,1 & 983393 & 32,5 & 12,44 \\
\hline $\begin{array}{l}\text { Кредити } \\
\text { юридич- } \\
\text { ним } \\
\text { особам }\end{array}$ & 911788 & 92,0 & 1052571 & 75,5 & 1298111 & 66,9 & 2040295 & 67,5 & 2,24 \\
\hline Усього & 990869 & 100 & 1393762 & 100 & 1940280 & 100 & 3023688 & 100 & 3,05 \\
\hline
\end{tabular}

*Джерело: складено автором на основі [5], [6].

Найбільше зростання обсягів кредитного портфеля банком спостерігалося у кредитування фізичних осіб, яке в 2020 році у 12,4 рази перевищує показник 2017 року. Відносно повільний темп зростання спостерігається у кредитуванні юридичних осіб - у 2020 році порівняно $з$ 2017-м він склав $123,7 \%$.

Зниження економічної активності внаслідок карантинних обмежень прямо відобразилося на доходах населення та погіршило фінансовий стан підприємств. Це ускладнило обслуговування позик, тож може призвести до істотного погіршення якості кредитного портфеля банків.

Також змінилася структура кредитного портфеля, зросла частка кредитів, наданих фізичним особам, яка у 2020 р. склала 32,5\%, а у 2017 р. була на рівні $8 \%$. Проте кредити юридичним особам надалі складають найбільшу частку кредитного портфеля банку і у 2020 р. становили 67,5\%. Збільшення кількості кредитів, наданих фізичним особам, може свідчити про зростання довіри населення до банківського сектору, вигідні умови кредитування та пом'якшення вимог банку до позичальника.

Структура кредитного портфеля за секторами економіки у 2017-2020 p.p. наведена у табл. 3. Такий аналіз проводиться для визначення надмірної концентрації кредитних операцій в одному сегменті, що підвищує ступінь кредитного ризику. 
Таблиця 3

Структура кредитного портфеля АТ АКБ “Львів” за секторами економіки у 2017-2020 рр., тис. грн*

\begin{tabular}{|l|c|c|c|c|c|c|c|c|}
\hline $\begin{array}{l}\text { Структура кредитів за видами } \\
\text { економічної діяльності }\end{array}$ & 2017 & $\%$ & 2018 & $\%$ & 2019 & $\%$ & 2020 & $\%$ \\
\hline Державне управління & 347 & 0 & 1149 & 0 & 0 & 0 & 0 & 0 \\
\hline $\begin{array}{l}\text { Виробництво та розподілення } \\
\text { електроенергії, газу та води }\end{array}$ & 5949 & 0 & 2471 & 0 & 92154 & 5 & 87888 & 3 \\
\hline Операції з нерухомим майном & 92886 & 7 & 118100 & 7 & 182843 & 9 & 237309 & 8 \\
\hline $\begin{array}{l}\text { Торгівля, ремонт автомобілів } \\
\text { та предметів особистого вжит- } \\
\text { ку }\end{array}$ & 166787 & 12 & 102378 & 6 & 603725 & 31 & 981574 & 32 \\
\hline $\begin{array}{l}\text { СГ, мисливство, лісове } \\
\text { господарство }\end{array}$ & 11938 & 1 & 11378 & 1 & 229323 & 12 & 428757 & 14 \\
\hline Фізичні особи & 799191 & 59 & 1033268 & 61 & 165275 & 8 & 235141 & 8 \\
\hline Переробна промисловість & 117901 & 9 & 138269 & 8 & 394906 & 20 & 598219 & 19 \\
\hline Будівництво & 33670 & 2 & 98269 & 6 & 48562 & 2 & 59516 & 2 \\
\hline $\begin{array}{l}\text { Транспорт, складське госпо- } \\
\text { дарство, поштова та кур'єрська } \\
\text { діяльність }\end{array}$ & 15353 & 1 & 25616 & 2 & 128555 & 7 & 203950 & 7 \\
\hline Інші & 115025 & 9 & 157779 & 9 & 120604 & 6 & 242505 & 8 \\
\hline Усього & 1359047 & 100 & 1688677 & 100 & 1965947 & 100 & 3074859 & 100 \\
\hline
\end{tabular}

*Джерело: складено автором на основі [5], [6].

Аналіз таблиці свідчить про те, що найбільший обсяг кредитування банку припадає на такі сектори економіки, як торгівля, ремонт автомобілів, побутових виробів та предметів особистого вжитку (32\%), переробна промисловість (19\%), сільське господарство, мисливство та лісове господарство $(14 \%)$.

Кредитування таких сфер, як виробництво, переробна промисловість, сільське господарство та торгівля, є першочерговим 3 огляду на те, що ці галузі дають найбільший мультиплікативний ефект в економіці, створюючи робочі місця в супутніх галузях.

Висновки i перспективи подальших досліджень у даному напрямі. Таким чином, кредитна діяльність банку здійснюється під впливом нестабільної фінансово-економічної та соціальної ситуації. Внаслідок проявів фінансової кризи банки змушені оперативно реагувати на зовнішні зміни та застосовувати сучасні методи управління ризиками. Під час аналізу кредитного портфеля АТ АКБ “Львів” виявлена позитивна динаміка кредитування фізичних осіб, що свідчить про збільшення довіри населення, а також про ефективну політику банку щодо управління кредитними ризиками. Вдосконалення управління кредитним портфелем повинно стосуватися теоретичних та практичних аспектів. 3 огляду на нестабільну макроекономічну ситуацію перспективи подальших досліджень мають бути направлені на розробку та впровадження сучасних інноваційних продуктів та послуг, а також підвищення конкурентоспроможності.

\section{ЛIТЕРАТУРА}

1. Адамик Б. П. Центральний банк і грошовокредитна політика : підручник / Адамик Б. П. [2-ге видання, доп. і переробл.]. - К. : Кондор, 2011. $-416 \mathrm{c}$.

2. Звіт керівництва (звіт про управління) АТ АКБ “Львів" за 2020 рік [Електронний ресурс]. Режим доступу: https://www.banklviv.com/wpcontent/uploads/2021/05/Zvit-kerivnytstva-2020final.pdf.

3. Мельник О. О. Проблемні кредити: аналіз якості кредитного портфеля банків України / Мельник О. О. // Науковий погляд: економіка та управління. - 2019. - Вип. 1 (63). - С. 200-211.

4. Степаненко К. Р. Особливості формування кредитного портфеля банку / К. Р. Степаненко // Науковий вісник Ужгородського національного університету. - 2016. - Вип. № 7. - С. 169.

5. Фінансова звітність АТ АКБ “Львів” станом на 31 грудня 2018 року: веб-сайт [Електронний pecypc]. - Режим доступу : https://www.banklviv.com/ wp-content/uploads/2019/10/FS_Lviv_ua_2018.pdf.

6. Фінансова звітність АТ АКБ “Львів” станом на 31 грудня 2020 року: веб-сайт [Електронний pecypc]. - Режим доступу: https://www.banklviv.com/ wp-content/uploads/2019/10/FS_Lviv_ua_2021.pdf.

\section{REFERENCES}

1. Adamyk, B. P. (2011), Tsentral'nyj bank i hroshovo-kredytna polityka : pidruchnyk, 2 nd ed, Kondor, K., 416 s.

2. Zvit kerivnytstva (zvit pro upravlinnia) AT AKB "L'viv" za 2020 rik, available at: 
Вісник Львівського торговельно-економічного університету. Економічні науки. №64, 2021

https://vvv.banklviv.tsom/vp-tsontent/uploads/2021/05/ Zvit-kerivnytstva-2020-final.pdf.

3. Mel'nyk, O. O. (2019), Problemni kredyty: analiz iakosti kredytnoho portfelia bankiv Ukrainy, Naukovyj pohliad: ekonomika ta upravlinnia, vyp. 1 (63), s. 200-211.

4. Stepanenko, K. R. (2016), Osoblyvosti formuvannia kredytnoho portfelia banku, Naukovyj visnyk Uzhhorods'koho natsional'noho universytetu, vyp. № 7, s. 169.
5. Finansova zvitnist' AT AKB “L'viv" stanom na 31 hrudnia 2018 roku: veb-sajt, available at: https://vvv.banklviv.tsom/vptsontent/uploads/2019/10/ FS_Lviv_ua_2018.pdf.

6. Finansova zvitnist' AT AKB "L'viv" stanom na 31 hrudnia 2020 roku: veb-sajt, available at: https://vvv.banklviv.tsom/vp-tsontent/uploads/2019/10/ FS_Lviv_ua_2021.pdf.

Стаття надійшла до редакиї 23 липня 2021 року 